\title{
Assessing the role of soil microbial communities of natural forest ecosystem
}

\author{
Gabi-Mirela Matei, Sorin Matei* and Victoria Mocanu
}

\begin{abstract}
In forests, edaphic microbial communities are involved in litter decomposition and soil forming processes, with major contribution to humification, especially bacteria and fungi being responsible for the main ecosystem services fulfilled by the soil. Research has been carried out aiming to characterize the structure and diversity of microbial communities in the Rendzic Leptosols (WRB) under natural deciduous forest from Visterna, Babadag Plateau and to assess their contribution to ecosystem services provided by soil. The paper presents the results of quantitative estimations and taxonomic composition of soil and litter communities of heterotrophic bacteria and fungi, identification of cellulolytic species, as well as the microbial biomass and global physiological activities expressed as soil respiration potential. More than a half of bacterial species were common in litter and soil (SI=57.14\%) and were represented by dominant species of fluorescent or non-fluorescent pseudomonads and Bacillus subtilis but no similarity was found between the two fungal communities. Fungal populations included cosmopolitan species, such as antagonists and strong cellulolytic representatives of genera Penicillium, Trichoderma, Mortierella, Chaetomium, Epicoccum, Aspergillus. Microbial density and microbial biomass presented the highest values in the litter $\left(684 \mathrm{mg} \mathrm{C} \mathrm{x} \mathrm{kg}^{-1}\right.$ d.s.) and in surface horizon Am1 of soil profile than in the bottom layers. The highest diversity was found in Am1 horizon $(0-5 \mathrm{~cm}) \mathrm{H}^{\prime}=1.983$ bits and $\varepsilon=0.869$ for cellulolytic community. Soil respiration reflected the intense physiological activity of microbiome, with high values associated to numerous effectives of bacteria and fungi especially in surface horizon. Microorganisms identified contribute to formation of soil by recycling of nutrients, cellulose decomposition, the synthesis of stable organic matter (humic acids), aggregation of soil particles, biological control of pathogens by antagonistic activity. They improve plant uptake of water and nutrients by forming symbioses (ectomycorrhizae), thus modelling the structure of vegetation.
\end{abstract}

Keywords: soil microorganisms, biodiversity, ecosystem services, cellulolytic species, biocontrol

National RD Institute for Soil Science, Agrochemistry and Environment, Bucharest, Romania

${ }^{*}$ Corresponding author: S. Matei E-mail: so_matei602003@yahoo.com

DOI: 10.2478/ebtj-2020-0001 (c) 2020 Authors. This work was licensed under the Creative Commons AttributionNonCommercial-NoDerivs 4.0 License.

\section{Introduction}

A wide component of global biodiversity in the world is represented by microbial diversity from soils. A high variety of bacteria and fungi have soil as habitat and these active decomposers represent the base of trophic chains, sustaining by their activities the diversity of superior trophic levels.

Soil is a rich source of microorganisms responsible for its most important functions in terrestrial ecosystems. Interaction between edaphic microorganisms and plants usually determines the biodiversity of vegetation (1).

Previous research carried out in forest ecosystems revealed that microbial communities are involved in soil forming processes, bringing a major contribution to litter decomposition and humus formation, as well as in conferring the character of suppressive soil by the capacity to control the development of various plant pathogens $(2,3)$.

Microbial communities can provide a measure of soil quality because they have the capacity to respond sensitively to changes and environmental stress (4). 
The modification of parameters characterizing microbiological communities can precede detectable changes in soil or plant properties, this being a sign of improving soil quality or an early warning of its deterioration $(5,6)$.

Plant-microbe-soil interactions were defined as drivers of plant community structure and dynamics (7).

Recent studies underlined the importance of microbiota for cycles of major elements and showed that global soil carbon projections could be improved by modelling microbial processes (8).

Analyzing the models of nitrogen cycling processes, scientists stressed the need to understand the structure and functioning of microbial communities in order to be able to predict ecosystem functions.

Once revealed the exceptional value of services provided by soil, it becomes important to realize the role of microbial diversity, the necessity to protect and to conserve this valuable natural resource represented by edaphic species of microorganisms (9).

The aim of present research was to assess the biodiversity and ecosystem services provided by the species from the structure of microbial communities in the Rendzic Leptosols (WRB) under the natural carpentry forest from Babadag Plateau at Visterna, Tulcea county, Romania.

\section{Materials and Methods}

Soil type (WRB) and ecosystem location: Rendzic Leptosols under natural deciduous forest from Babadag plateau, Visterna, Tulcea County, Dobrogea, Romania (sampling site coordinates: $44^{\circ} 51^{\prime} 34^{\prime \prime} \mathrm{N}$ latitude and $28^{\circ} 46^{\prime} 16^{\prime \prime} \mathrm{E}$ longitude). The ecosystem Babadag forest is in the Nature 2000 site (Romanian Code ROSPA0091) (10) and EUR 27: $91 \mathrm{YO} \mathrm{-} \mathrm{Dacian} \mathrm{oak-hornbeam}$ forest (according to description for the Manual EUR 27)R4: Habitat of community interest, type: habitat met only in Dobrogea, 41.7633 (Dobrogean Quercus pedunculiflora-limeoriental hornbeam forests). The majority of the worldwide areal is in this site (11).

Soil samples were taken from soil profile pit according to genetic horizons described and from surface organic horizon (Ol) represented by undecomposed plant litter (dead leaves, bark, needles, twigs and cladodes that have fallen to the ground).

Microbiological analysis of soil samples was performed by plating soil decimal dilutions on specific solid culture media (Topping for heterotrophic aerobic bacteria, PDA for fungi and
Stapp for cellulolytic microorganisms). After incubation in the dark at $25^{\circ} \mathrm{C}$ for 5 days, microbial colonies were counted and results were expressed as viable cells for bacteria and colony forming units for fungi, reported to gram of dry soil.

Micrographs have been done to reveal, by optical microscopy, the morphological aspects of microorganisms developed.

Taxonomic identification of bacteria was done according to Bergey's manual (12). Fungi were identified according to determinative manuals $(13,14)$.

The microbial biomass and global physiological activities of microflora were determined by substrate induced respiration


respectively $\mathrm{mg} \mathrm{CO}_{2} \times 100 \mathrm{~g}^{-1}$ soil (15).

Ecological parameters (structural indices) represented by the total counts, relative abundance, species richness (S), species diversity $\left(\mathrm{H}^{\prime}\right)$, homogeneity (equitability) $(\varepsilon)$ and species frequency revealed the particularities of each community and the status of a certain species.

The frequency of each taxa registered allowed their grouping in 4 classes of constancy, respectively in euconstant, constant, accessory and accidental taxa (16).

Similarity indices (SI) were calculated between litter and soil communities for both bacteria and fungi (17).

Statistical analysis. The data collected have been statistically processed and interpreted by one-way analysis of variance (ANOVA). Values represent the mean of three replicates /setup. The value of $\mathrm{P}<0.05$ was regarded as statistically significant (Student test).

\section{Results}

Soil from Babadag plateau presented the highest values of bacterial counts in $A m_{1}(0-5 \mathrm{~cm})$ surface horizon, with one order of magnitude superior to the values registered for the litter and a very high density of fungi, corresponding to the high quantity of humus $(16.30 \%)$ and major nutrients in this horizon $\left(\mathrm{Nt}=0.711 \%, \mathrm{P}_{\mathrm{AL}}=16 \mathrm{mg} / \mathrm{kg}, \mathrm{K}_{\mathrm{AL}}=576 \mathrm{mg} / \mathrm{kg}\right)$.

An important bacterial community was present in $\mathrm{Am}_{2}$ horizon but the number of fungi decreased one order of magnitude.

In horizon $\mathrm{Amq}_{1}(20-35 \mathrm{~cm})$, low bacterial counts registered but fungal community developed moderately, with slightly higher density than in $\mathrm{Am}_{2}$ horizon (Table 1).

The physiological activities of microflora were extremely

Table 1. Microbial counts and soil respiration in Rendzic Leptosols from Visterna - Babadag Plateau

\begin{tabular}{|c|c|c|c|}
\hline $\begin{array}{l}\text { Horizon/ } \\
\text { Depth }(\mathrm{cm})\end{array}$ & $\begin{array}{c}\text { Fungal counts } \\
\text { ( } \times 10^{3} \mathrm{cfu} \times \mathrm{g}^{-1} \text { dry soil) }\end{array}$ & $\begin{array}{c}\text { Bacterial counts } \\
\left(\times 10^{6} \text { viable cells } \times g^{-1} \text { dry soil) }\right.\end{array}$ & $\begin{array}{l}\text { Soil respiration potential } \\
\left(\mathrm{mg} \mathrm{CO} \mathrm{C}_{2} \times 100 \mathrm{~g}^{-1} \text { soil) }\right.\end{array}$ \\
\hline Ol (5-0) & $149.880 b^{*}$ & $414.733 c$ & $170.804 a$ \\
\hline $\mathrm{Am}_{1}(0-5)$ & $220.154 a$ & $4529.007 a$ & $146.418 b$ \\
\hline $\mathrm{Am}_{2}(5-20)$ & 48.993d & $3996.211 b$ & $114.823 d$ \\
\hline $\mathrm{Amq}_{1}(20-35)$ & $60.514 c$ & $3.804 d$ & $127.122 c$ \\
\hline
\end{tabular}

*Different letters indicate significant differences among values in a column at $\mathrm{P}<0.05$ 


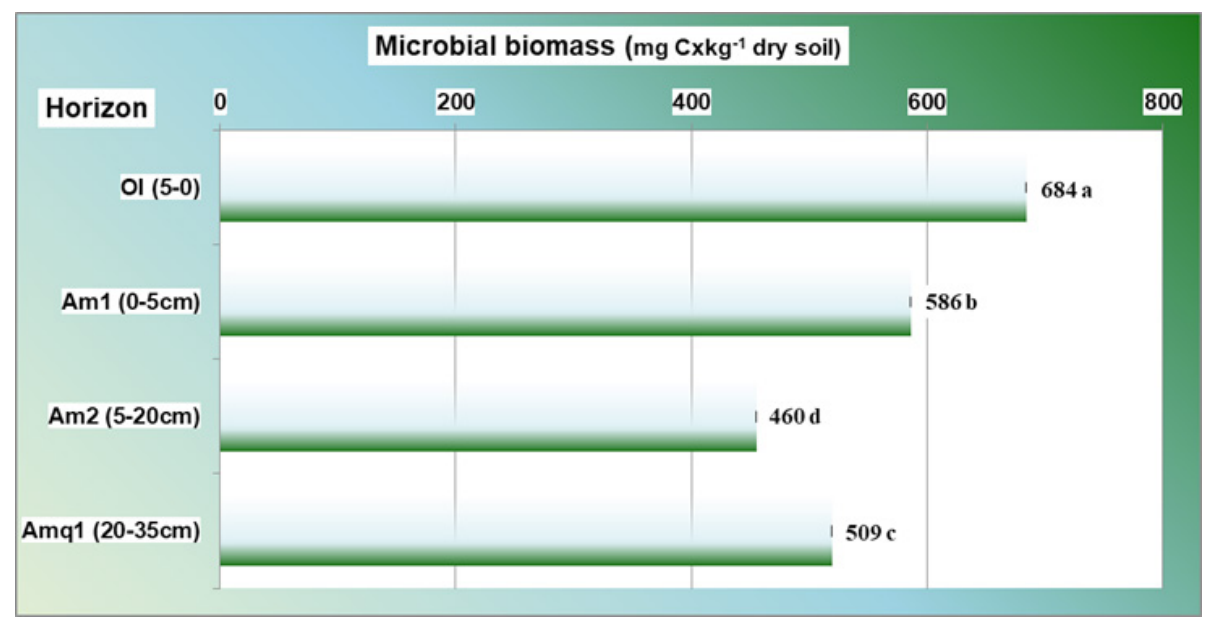

Figure 1. Microbial biomass in Rendzic Leptosols from Babadag Plateau.

intense, with high values of respiration, associated to numerous effectives of bacteria and fungi especially in litter and Am1 horizon.

Microbial biomass (Fig. 1) presented the highest values in the litter (684 mg C x kg-1 d. s.) and in surface horizon Am1
(0-5 cm) (586 mg C x kg-1 d. s.).

Community of heterotrophic aerobic bacteria was dominated by species belonging to the pseudomonads, characteristic for horizons rich in humus and major nutrients, accompanied by Bacillus subtilis.

Table 2. Taxonomic composition of bacterial and fungal communities in litter and Rendzic Leptosols from Babadag plateau (Visterna)

\begin{tabular}{|c|c|c|c|}
\hline $\begin{array}{l}\text { Horizon/ } \\
\text { Depth }(\mathrm{cm})\end{array}$ & $\begin{array}{l}\text { Bacterial species } \\
\text { (Topping) }\end{array}$ & $\begin{array}{l}\text { Fungal species } \\
\text { (PDA) }\end{array}$ & $\begin{array}{l}\text { Cellulolytic species } \\
\text { (Stapp) }\end{array}$ \\
\hline $\begin{array}{l}\text { OI } \\
(5-0)\end{array}$ & $\begin{array}{l}\text { Pseudomonas fluorescens, } \\
\text { Pseudomonas sp., } \\
\text { Bacillus subtilis } \\
\text { Bacillus megaterium, } \\
\text { Bacillus circulans, } \\
\text { Serratia marcescens } \\
\text { Actinomycetes Series Albus }\end{array}$ & $\begin{array}{l}\text { Penicillium janthinellum, } \\
\text { Absidia corymbifera, Penicillium } \\
\text { sp., } \\
\text { Paecilomyces sp. }\end{array}$ & $\begin{array}{l}\text { Myrothecium catenulatum, } \\
\text { Mortierella nana, Chaetomium } \\
\text { globosum, Chaetomium spirale, } \\
\text { Mortierella alpina, } \\
\text { Actinomycetes }\end{array}$ \\
\hline $\begin{array}{l}\mathrm{Am}_{1} \\
(0-5)\end{array}$ & $\begin{array}{l}\text { Pseudomonas fluorescens, } \\
\text { Pseudomonas pseudogleyi, } \\
\text { Bacillus subtilis } \\
\text { Actinomycetes Series Fuscus }\end{array}$ & $\begin{array}{l}\text { Mortierella minutissima, } \\
\text { Cladosporium herbarum, } \\
\text { Trichoderma viride, Penicillium } \\
\text { nigricans, } \\
\text { Fusarium oxysporum }\end{array}$ & $\begin{array}{l}\text { Cytophaga sp., } \\
\text { Chaetomium spirale, Mortierella } \\
\text { minutissima, } \\
\text { Stysanus stemonitis, Mortierella } \\
\text { alpina, } \\
\text { Humicola grisea, } \\
\text { Epicoccum nigrum, } \\
\text { Actinomycetes Series Fuscus }\end{array}$ \\
\hline $\begin{array}{l}\mathrm{Am}_{2} \\
(5-20)\end{array}$ & $\begin{array}{l}\text { Pseudomonas fluorescens, } \\
\text { Bacillus cereus var. mycoides, } \\
\text { Bacillus subtilis }\end{array}$ & $\begin{array}{l}\text { Trichoderma viride, Penicillium } \\
\text { nigricans }\end{array}$ & $\begin{array}{l}\text { Mortierella minutissima, } \\
\text { Epicoccum nigrum, Mortierella } \\
\text { alpina, } \\
\text { Verticillium tenerum, } \\
\text { Mortierella verticillata, Cytophaga } \\
\text { sp., } \\
\text { Actinomycetes }\end{array}$ \\
\hline $\begin{array}{l}\mathrm{Amq}_{1} \\
(20-35)\end{array}$ & $\begin{array}{l}\text { Bacillus megaterium, } \\
\text { Pseudomonas sp., } \\
\text { Pseudomonas fluorescens, } \\
\text { Bacillus subtilis }\end{array}$ & $\begin{array}{l}\text { Penicillium chrysogenum, } \\
\text { Aspegillus fumigatus, Penicillium } \\
\text { nigricans, Phialophora fastigiata, } \\
\text { Mortierella minutissima, } \\
\text { Mycelia of basidiomycetes }\end{array}$ & $\begin{array}{l}\text { Cytophaga sp., } \\
\text { Mortierellla verticillata, } \\
\text { Mycelia of basidiomycetes, } \\
\text { Absidia corymbifera, Mortierella } \\
\text { minutissima, } \\
\text { Actinomycetes Series Griseus and } \\
\text { Albus }\end{array}$ \\
\hline
\end{tabular}




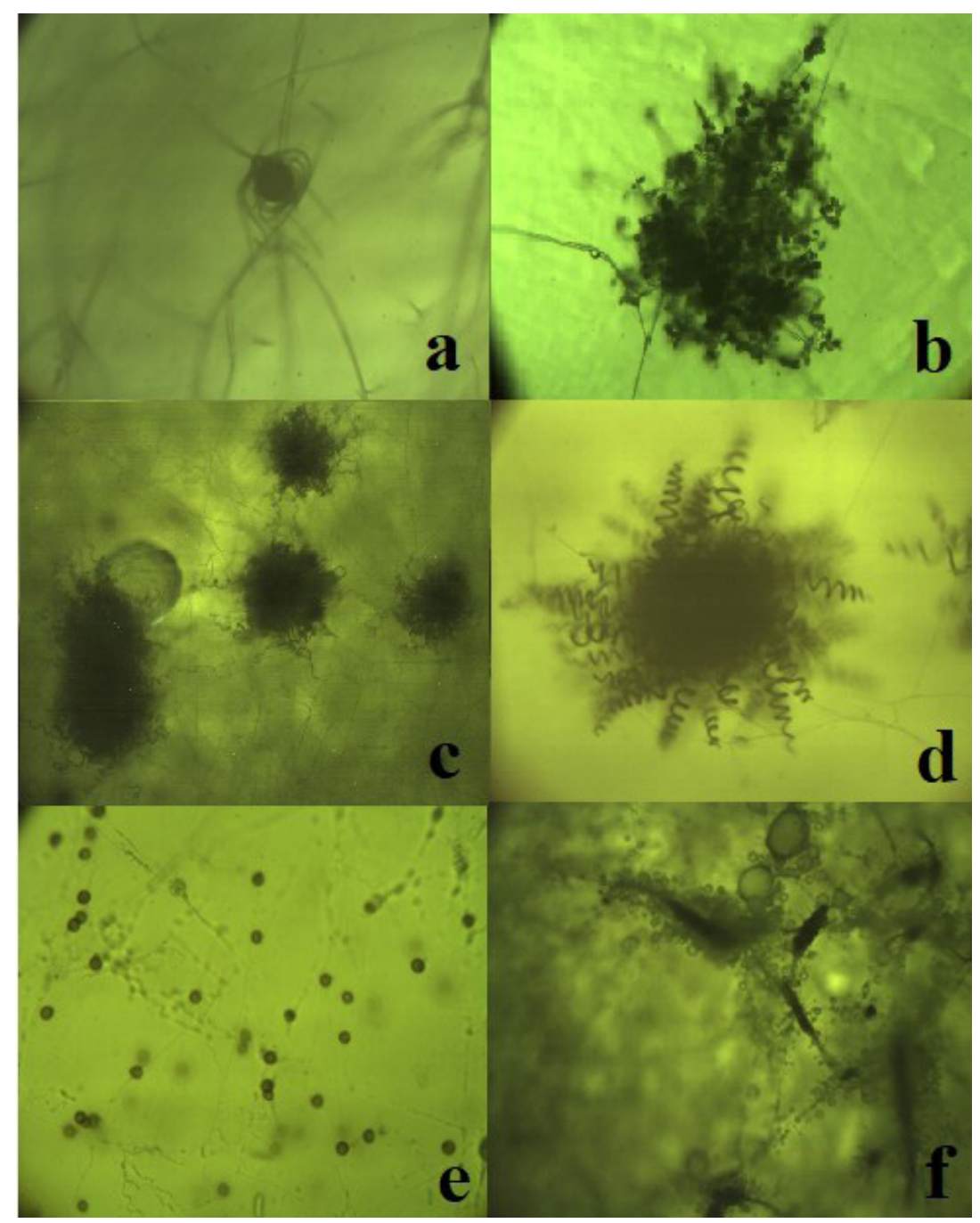

Figure 2. Cellulolytic microflora: a) Absidia corymbifera (azygospore) from litter (300x), b) Trichoderma viride from soil (300x), c) Chaetomium globosum from litter (60x), d) Chaetomium spirale from soil (150x), e) Humicola grisea (300x), f) Stysanus stemonitis and Mortierella sp.(60x).

Species Bacillus megaterium was the most numerous in horizon from the bottom of profile.

The presence of Actinomycetes was evidenced especially in the litter and in soil surface layer $\left(\mathrm{Am}_{1}\right)$, too. The structures belonging to 2-3 different species presented cellulolytic abilities (evidenced on Stapp medium) (Table 2). Species diversity was higher in litter $(S=7)$ than in soil horizons, where 3 to 4 species were identified in a community.

Homogeneity $\varepsilon$ as well as diversity index $H^{\prime}$ values were lower in bacterial community from soil $\left(\varepsilon=0.160, H^{\prime}=0.316\right.$ bits) than in litter $\left(\varepsilon=0.560, \mathrm{H}^{\prime}=1.161\right.$ bits $)$.

Similarity index (SI) value of $57.14 \%$ showed that more than a half of bacterial species were common in litter and soil and were represented by fluorescent or non-fluorescent pseudomonads and Bacillus subtilis.

These fluorescent pseudomonads and Bacillus subtilis were considered as euconstant species in this soil, followed as frequency by non-fluorescent pseudomonads and Bacillus megaterium and by accessory species, including Pseudomonas pseudogleyi, Serratia marcescens, Bacillus circulans and actinoycetes, less frequent (25\%) and dependent of the presence of various substrates or by their accessibility.

A number of 4 species was identified (on PDA medium) in fungal communities from litter and 2 to 6 species in soil.

Diversity index in litter was $\mathrm{H}^{\prime}=1.310$ bits and the community presented the highest values of homogeneity $(\varepsilon=0.872)$, reflecting the most homogenous repartition of individuals on species as compared with less homogenous repartition in bacterial communities, where few species (generally belonging to pseudomonads) developed high effectives and the rest of species were represented in low effectives.

Diversity index was higher in soil communities from Am1 horizon $\left(\mathrm{H}^{\prime}=1.343\right.$ bits $)$ and Amq1 $\left(\mathrm{H}^{\prime}=1.676\right.$ bits $)$ but lower in $\mathrm{Am} 2\left(\mathrm{H}^{\prime}=0.673\right.$ bits $)$.

Fungal microflora was dominated by saprotrophic cosmopolite species from genera Penicillium, characteristic for temperate regions and Trichoderma present as constant species.

Genus Aspergillus, more thermophilic was less well represented. 
Table 3. Ecosystem services carried out by microbial communities in Rendzic Leptosols

Ecosystem services

Organic matter decomposition and cycling

\author{
Improving nutrients availability and \\ uptake
}

\section{Suppression (inhibition) of plant pathogens}

\section{Plant growth control} Improving soil structure and hydrological
processes

\section{Regulation of gas exchange and carbon sequestration}

\section{Microorganisms providing the services}

Bacteria, actinomycetes, fungi, especially belonging to cellulolytic group (e.g species from genera Cytophaga, Chaetomium, Mortierella, Epicoccum)

Majority of bacteria, actinomycetes (nitrogen mineralizing species of Streptomyces from Series Griseus), microfungi, ecto or endo-mycorrhizal fungi forming symbioses with trees (e.g. basidiomycetes )

Antagonistic species of bacteria (e.g. Pseudomonas fluorescens), actinomycetes, fungi (e.g. Trichoderma viride, Paecilomyces sp.)

Plant growth promoting microorganisms, mycorrhizal fungi, biocontrol agents (antagonists for pathogens)

Bacteria producing exopolysaccharides (pseudomonads), actinomycetes, fungi, (e.g. species from genera Humicola, Trichoderma, Myrothecium, Cladosporium), mycorrhizal fungi, all contributing to formation of soil aggregates

Microorganisms from all groups, mostly from cellulolytic group
Cellulolytic microflora was rich, with 6 species identified in litter, $H^{\prime}=1.692$ bits and $\varepsilon=0.867$.

Cellulolytic species from soil (7 to 8 in communities from each horizon) were represented by bacteria from genus Cytophaga, well developed in horizon Am $(0-5 \mathrm{~cm})$ and accompanied by species of genus Mortierella (Mortierella minutissima and Mortierella alpina characteristic for neutral or alkaline soils).

Generally, the structure of community represented by cellulolytic microflora included species of genera Mortierella, Chaetomium, bacteria Cytophaga and actinomycetes as euconstant or constant species, Epicoccum, basidiomycetes as accessory species and accidental species, such as Myrothecium catenulatum present as dominant species only in litter $(\mathrm{Ol})$ but with high abundance $(A=27.2 \%)$, probably involved in a certain stage of decomposition of organic material of vegetal origin.

The presence of Trichoderma viride (Fig.2b) with antagonistic and cellulolytic capabilities and of species Humicola grisea (Fig.2e) with role in processes of humification was evidenced in mollic surface horizons.

These fertile surface horizons are the defining diagnostic feature of Mollisols and result from the long-term addition of organic materials derived from plant roots transformed by microbiological activity and typically have soft, granular soil structure (the Latin mollis, meaning soft).

The highest value of diversity index was found in Am1 horizon $(0-5 \mathrm{~cm})$ with $H^{\prime}=1.983$ bits and $\varepsilon=0.869$ for cellulolytic community.

Other strong cellulolytic species were identified: Epicoccum nigrum, Chaetomium globosum (Fig.2c), Chaetomium spirale (Fig.2d), Stysanus stemonitis (Fig.2f), Absidia corymbifera (Fig.2a) and mycelia of basidiomycetes (in the bottom of soil profile).

Many of actinomycetes from Series Fuscus and Griseus, fluorescent pseudomonads and fungi from genera Penicillium, Cladosporium, Mortierella, Humicola, Epicoccum, Trichoderma, Verticillium isolated from rendzic leptosols from Babadag plateau presented the capacity to synthesize and to release a series of coloured pigments acting as natural precursors incorporable into stable forms of organic matter (humic acids).

A synthesis of the role of microbial communities in ecosystem services carried out by the forest soil studied is presented in Table 3.

\section{Discussion}

In the present research, the highest microbial counts and microbial biomass were detected in the litter and in surface horizon Am1 $(0-5 \mathrm{~cm})$.

The physiological activities of microflora associated to numerous effectives of bacteria and fungi in these surface horizons were extremely intense, as evidenced by high values of respiration potential.

The results of the research carried out on PDA medium for fungal communities from litter (Ol) demonstrated a high diversity of species, with the highest values of equitability. This reflected a homogenous repartition of individuals on species as compared with less homogenous repartition in bacterial communities, where few species (generally belonging to pseudomonads) developed high effectives and the rest of species were represented in low effectives.

Cellulolytic microflora (on Stapp medium) identified in litter was rich and presented a high homogeneity as distribution of effectives on species.

Cellulolytic species from soil (with higher diversity) were represented by bacteria Cytophaga, abundant in surface horizon and accompanied by species Mortierella minutissima and Mortierella alpina. As in our research, both species were isolated in association with Penicillium nigricans, especially 
from calcareous soils and the rhizosphere (18).

Their presence, as well as of representatives from other genera (Chaetomium, Epicoccum, Cladosporium, Stysanus) was linked to the high content of organic matter, being considered as possessing high abilities for enzyme-mediated hydrolytic activities involved in cellulose and chitin decomposition.

The highest diversity for cellulolytic community was found in mollic surface horizons where Trichoderma viride with antagonistic and cellulolytic capabilities and Humicola grisea with role in humification were identified.

Research carried out recently $(19,20)$ confirmed the importance of various species of Trichoderma in the biological control of plant pathogens in natural or agro-ecosystems.

Other results (21) evidenced the services of this species in high residues farming systems, by the ability to colonize plant residues and soil, generating a suppressive environment that reduces the risk of infections with pathogens or by activation of plant defence response. Authors reported the positive influence of using biostimulative inoculum with Trichoderma strain on soil microbiota that improved biological soil aeration/"biological tillage" and enhanced plant resistance to abiotic and biotic stress.

Mycelia of basidiomycetes were present on PDA medium and on Stapp in the fungal community of the Amq1(20-35 $\mathrm{cm}$ ) horizon. It is well known the role of basidiomycete species in forming symbiotic associations with the roots of forest trees (ectomycorrhizae). By their enormous hyphal network spread into the soil, fungi can mobilize nutrients from mineral insoluble forms, increase water and micronutrients uptake, thus sustaining plants growth, increased resistance to high temperature or soil acidity and conferring natural protection against pathogen attack (22).

Microorganisms identified in Rendzic Leptosols from Babadag plateau contribute to formation of soil by recycling of nutrients, cellulose decomposition and the synthesis of stable organic matter (humic acids). Microbial metabolites produced by bacteria and the presence of fungal hyphae are essential for soil aggregation, improving soil structure and making it more favourable for plants development.

Other authors reported the beneficial role of various microbial species from soils in adjusting the composition of community and preventing the proliferation of pathogenic species (23). This service depends on soil properties and biological processes governing inter and intraspecific interactions (symbiosis, competition, predation).

Edaphic microorganisms are implicated in carbon sequestration as stable organic matter and the control of $\mathrm{CO}_{2}$ emission (8).

Results from the present research are in concordance with data from literature reporting that antagonistic microbial species belonging to the actinomycetes, pseudomonads or fungal strains of Trichoderma confer the character of suppressive soil $(24,25,26)$.

This confirm the capacity of this soil to offer conditions favourable for an equilibrate microbiota that is able to keep under control the development of pathogenic species.

These soil microorgansims produce various metabolites mainly with antimicrobial action $(27,28)$ and enzymes that could be utilized for biotechnological purposes (29).

Non-polluting methods of biocontrol can be tested with the aid of selected microbial strains, based on their antagonistic or immunity eliciting properties $(30,31,32)$.

Further research is needed for a better understanding of microbial communities from various ecosystems, their functioning and composition, interaction between them and interaction with other groups of organisms, to improve methods of conservation of biodiversity and to find new means to include their beneficial capabilities in environment protection strategies.

\section{Conclusions}

Rendzic leptosol from Babadag plateau (Visterna) presented high values of bacterial and fungal counts in litter and soil surface horizon and moderate to low towards less aerated layers from the bottom of soil profile.

Highest accumulation of microbial biomass was recorded in the litter and in soil surface horizon Am1.

Global physiological activity of microflora expressed as soil respiration potential was very intense, with high values of $\mathrm{CO}_{2}$ released.

The highest value of diversity index was found in Am1 horizon $(0-5 \mathrm{~cm})$ with $H^{\prime}=1.983$ bits and $\varepsilon=0.869$ for cellulolytic community.

Bacterial communities presented fluorescent pseudomonads, bacillaceae and actinomycetes as dominant species in both litter and soil ( $\mathrm{SI}=57.14 \%)$.

Fungal populations included cosmopolitan species, antagonists and strong cellulolytic such as representatives of dominant genera Penicillium, Trichoderma, Mortierella, Chaetomium, Cladosporium, Epicoccum, Aspergillus.

Microorganisms identified contribute to formation of soil by recycling of nutrients, cellulose decomposition, the synthesis of stable organic matter (humic acids), aggregation of soil particles, biological control of pathogens by production of active metabolites.

The presence of antagonistic microflora and the absence of soil-borne plant pathogens are arguments supporting the suppressive character of this soil (intrinsic capacity of soil to inhibit the development of potential plant pathogenic species by biological control mediated by antagonistic components of its microbial communities).

By its biodiversity, litter and forest soil microflora can be a natural source of new performant strains for biotechnologies of bioremediation or soil quality improvement.

\section{Acknowledgements}

This paper was supported by National Authority for Scientific Research and Innovation by Research Programme NUCLEU, the project PN 193404 01/2019. 


\section{Conflict of Interest}

The authors declare that they have no conflicts of interest.

\section{Ethical Compliance}

This article does not contain any studies involving human participants or animals performed by any of the authors.

\section{References}

1. Aislabie J, Deslippe J. Soil microbes and their contribution to soil services. In: Dymond JR ed. Ecosystem services in New Zeelandconditions and trends. Manaaki Whenua Press, Lincoln, New Zeeland, 2013.

2. Weller DM, Raaijmakers JM, McSpadden Gardener BB, Thomashow LS. Microbial populations responsible for specific soil suppressiveness to plant pathogens. Annu Rev Phytopatol 2002; 40: 309-348.

3. Matei GM, Matei S, Mocanu V, Dumitru S. Microbiological characterization of suppressive forest soil from Enisala. Ann Univ Craiova Agricultura - Montanologie - Cadastru 2016; 46: 341-347.

4. Cornea PC, Voaideş C, Ciucă M, Stan V, Gameț E, Razec I, Duşa M. Molecular methods for assessment the bacterial communities from different types of soils in Romania. Not Bot Hort Agrobot Cluj 2011; 39(1): 64-70.

5. Meyer O. Functional Groups of Microorganisms. In Book: Biodiversity and Ecosystem Function. Schulze \& Mooney (eds.), Springer-Verlag, Berlin Heidelberg, 1994; p.67- 96.

6. Winding A, Hunt-Rink EK, Rutgers M. The use of microorganisms in ecological soil classification and assessment concepts. Ecotoxic Environ Safety 2005; 62: 230-248.

7. Reynolds HL, Packer A, Bever JD, Clay K. Grassroots ecology: plantmicrobe-soil interactions as drivers of plant community structure and dynamics. Ecology 2003; 84: 2281-2291.

8. Wieder WR, Bonan GB, Allison SD. Global soil carbon projections are improved by modelling microbial processes. Nat Clim Change 2013; 3: 909-912.

9. Graham WR, Leff JW, Weintraub SR, Townsend AR et al. Do we need to understand microbial communities to predict ecosystem function? A comparison of statistical models of nitrogen cycling processes. Soil Biol Biochem 2014; 68: 279-282.

10. INCDS "MARIN DRĂCEA" \& P.F.A. FĂGĂRAȘ V. MARIUS MIRODON. Studiu pentru evaluarea adecvată a efectelor potenţiale asupra ariilor naturale protejate de interes comunitar din cadrul ocolului silvic Babadag Direcţia silvică Tulcea Judeţul Tulcea (Study for adequate evaluation of potential effect on natural protected areas of community interest from "Ocolul silvic Babadag" Forestry direction Tulcea, Tulcea county. 2017. http://www.anpm.ro/ documents/28797/2388743/SEA+OS+BABADAG_FINAL++Prof.+M.+Fagaras+2017.pdf/efc53b96-e022-4955-a83ce6e605d5df56

11. Gafta D, Muntford O.(coord.). Romanian Manual for Interpretation of EU Habitats (in Romanian), 2008. Ed RISOPRINT, Cluj-Napoca, 104pp. http://www.risoprint.ro/detaliicarte.php?id=596

12. Bergey DH, Holt JG. Bergey's manual of determinative bacteriology 9, Eds. Williams \& Wilkins, Baltimore, 1994.

13. Domsch KH, Gams W. Fungi in agricultural soils. T\&A Constable Ltd. Edinburg, London, 1970.

14. Watanabe T. Pictorial Atlas of Soil and Seed Fungi: Morphologies of Cultured Fungi and Key to Species $2^{\text {nd }}$ ed. CRC PRESS, Boca Raton London, New York, Washington D.C., 2002.

15. Matei $S$. Determination of soil respiration and microbial biomass In: Dumitru M, Manea A (coord.). Methods of chemical and microbiological analysis (utilized in soil monitoring system), (in Romanian). Ed. SITECH, Craiova, 2011; p.283-288.
16. Mohan Gh, Ardelean I. Ecology and environment protection (in Romanian). Ed SCAIUL, Bucharest, 1993.

17. Tiwari SC, Tiwari BK, Mishra RR. Succession of microfungi associated with the decomposing litters of pineapple (Ananas comosus). Pedobiol 1994; 38: 185-192.

18. Papacostea P. Biologia solului. Ed Științifică și Enciclopedică, Buc. 1976.

19. Ahmed MFA. Evaluation of some biocontrol agents to control Thompson seedless grapevine powdery mildew disease. Egypt J Biol Pest Cont 2018; 28:93 doi: 10.1186/s41938-018-0098-0.

20. Kaushal S, Chandel S, Sharma M, Kashyap P. Morphological and molecular diversity study among the isolates of Trichoderma using RAPD markers. Int J Chem Stud 2018; 6(4): 1731-1735.

21. Oancea F, Răut I, Șesan TE, Jecu L. Trichoderma strains as plant biostimulants in high residues farming systems. In book: Trichoderma spp. - applications in agriculture and horticulture, Chapter 7, Ed. Univ, Bucharest, 2017; p. 336-383.

22. Garay-Serrano E, Ortega-larrocea P, Reverchon F, Suarez-Quijada I. Persistence of ecto- and ectendomycorrhizal fungi associated with Pinus montezumae in experimental microcosm. Symbiosis 2017; 1-12, on- line, DOI: 10.1007/s13199-017/-0496-1, Springer. https://slideheaven.com/persistence-of-ecto-andectendomycorrhizal-fungi-associated-with-pinus-montezuma. html.

23. Alabouvette $C$, Steinberg $C$. The soil as a reservoir for antagonists to plant diseases. In: An Ecological Approach and Societal Approach to Biological Control. Prog Biol Cont 2006; 2: 123-144.

24. Kucuc C, Kivanc M. Isolation of Trichoderma spp. and determination of their antifungal, biochemical and physiological features. Turk J Biol 2003; 27: 247-253.

25. Matei S, Matei GM, Cornea P, Popa G. Characterization of soil Trichoderma isolates for potential biocontrol of plant pathogens. Soil Forming Factors and Processes from the Temperate Zone 2011; 10S. new series: 29-37.

26. Bonilla N, Cazorla FM, Martinez-Alonso M, Hermoso JM, GonzalesFernandez J, Gaju N, Landa BB, de Vicente A. Organic amendments and land management affect bacterial community composition, diversity and biomass in avocado crop soils. Plant Soil 2012; 357: 215-226.

27. Mapari S, Nielsen K, Larsen T, Frisvad J, Meyer A, Thrane U. Exploring fungal biodiversity for the production of water-soluble pigments as potential natural food colorants. Curr Op Biotechnol 2005; 16 (2): 231-238.

28. Hassan S, Gupta G, Anand S, Chaturvedi A, Kaur H. Biopotential of microbial antagonists against soil borne fungal plant pathogens. Int J Agr Food Sci Technol 2013; 4(2): 37-39.

29. De Marco JL, Inglis MC, Felix CE. 2003 Production of hydrolytic enzymes by Trichoderma isolates with antagonistic activity against Crinipellis perniciosa, the causal agent of witches broom of cocoa. Brazilian J Microbiol 2003; 34: 33-38.

30. Hanson LE, Howell CR. Elicitors of plant defense responses from biocontrol strains of Trichoderma virens. Phytopatol 2004; 94: 171176.

31. Namdeo AG. Plant cell elicitation for production of secondary metabolites: a review. Pharcognosy Rev 2007; 1: 69-79.

32. Matei GM, Matei $\mathrm{S}$. Research on isolation, characterization and testing the interaction between Trichoderma harzianum and Botrytis cinerea for biological control of gray mold in strawberry. Lucr St USAMVB, Series B, 2008; 51: 653-657. 